Величко О.Г., Мяновська Я.В., Карбовничек М., Ду Юньшен, Мішалкін А.П., Камкіна Л.В.

Безвідходна окислювальна дефосфорація високофосфористих марганцевих сплавів за участю охолоджувачів плавки Velichko O., Myanovska Ya., Karbovnichek M., Du Yunshen, Mishalkin A., Kamkina L.

\title{
Refining of manganese alloys with high content of phosphorus obtained in electrometallurgical dephosphoration of manganese ores
}

\begin{abstract}
Підтверджена доцільність проведення процесу дефосфрорації сплаву в одну стадію з використанням брикетованої суміші, яка включає залізну окалину, вапно, боксит та ортосилікат натрію при їх наступному співвідношенню, ваг.\%: залізна окалина - 52,0..57,4; вапно - 6,2..8,6; боксит - 4,5..6,2; ортосілікат натрію 30,5...30,4. Досягнута ступінь дефросфорації супутнього марганцевого сплаву становить біля 70\%, вміст марганцю в сплаві - 64,6\%. Реалізація дефосфорації за розробленим способом дозволила підвищити коефріцієнт наскрізного вилучення марганцю з вихідної сировини. Виключення зі складу матеріалів для дефоосфорації фртористих з'єднань підвищує екологічну чистоту процесу рафрінування. В реальних умовах виробниитва при здійсненні процесу дефоссрорації супутнього сплаву можливо застосування різних схем обробки та умов його проведення. При утворенні супутнього сплаву з температурою $\sim 1300^{\circ} \mathrm{C}$ в умовах виробництва малофросфористого шлаку, з метою мінімізації витрат на проведення дефоссрорації сплаву з використанням наявного обладнання цеху, проведення процесу рафрінування може бути реалізовано за наступною схемою у разі наявності установки піч - ківш для зов-нішнього підігріву розплаву та продувки ванни аргоном схема процесу дефросфрорації може включати проведення наступних операцій: присадка 100\% попередньо брикетованої ШУС, на дно ковша, транспортування ковша на установку піч-ковш, де буде підтримуватися по ходу рафрінування оптимальна температура. Це дозволить збільшити час рафрінування, а відповідно и більшу повноту протікання процесу рафрінування.:

Ключові слова: високо фосфористий супутній сплав, шлакоутворююча суміш, піч-ківш, повнота дефоссрораuiii.

The expediency of carrying out the process of dephosphorization of the alloy in one stage using a briquetted mixture, which includes iron scale, lime, bauxite and sodium orthosilicate in their following ratio, wt.\%: Iron scale - 52.0... 57.4 lime - 6.2... 8.6; bauxite - 4.5.. 6.2; sodium orthosilicate - 30.5 .. 30.4. The achieved degree of dephosphorization of the accompanying manganese alloy is about $70 \%$, the manganese content in the alloy - $64.6 \%$. The implementation of dephosphorization according to the developed method allowed to increase the rate of throughput of manganese from the raw material. Exclusion from the composition of materials for dephosphorization of fluoride compounds increases the environmental friendliness of the refining process. In the real conditions of production in the process of depho?phorization of the associated alloy may use different processing schemes and conditions of its implementation. In the formation of a concomitant alloy with a temperature of $\sim 13000 \mathrm{C}$ in the production of low-phosphorus slag, in order to minimize the cost of dephosphorization of the alloy using existing shop equipment, the refining process can be implemented according to the following scheme and purging the bath with argon, the dephosphorization process scheme may include the following operations: adding 100\% pre-briquetted SHUS, to the bottom of the bucket, trans?orting the bucket to the installation of the oven-bucket, where the optimum temperature will be maintained during refining. This will increase the refining time and, consequently, greater completeness of the refining process .:

Key words: highly phosphorous concomitant alloy, slag-forming mixture, ladle furnace, completeness of depho?phorization.
\end{abstract}

\section{ВСТУП}

Розробка інноваційних технологічних рішень на основі збалансованого використання матеріалів природного ресурсної бази $є$ основою забезпечення в сучасних умовах стабільності і підвищення основних показників виробництва феросплавів. Основними завданнями, що стоять перед дослідниками є підвищення коефіцієнта наскрізного вилучення провідних елементів з вихідної природної сировини і збільшення випуску товарної продукції високої якості при зменшенні кількості техногенних відходів, які утворюються в процесах переробки природної сировини та важко утилізуються.

Відомі ряд технологічних рішень [1], які можуть бути використані при дефосфорації сплавів на основі марганцю і хрому. Перехід фоссрору зі сплаву в шлак при їх рафінуванні забезпечується за рахунок створення відновлювальних або слабоокислювальних умов з використанням різних реагентів для здійснення рафрінування в широкому діапазоні температур $\left(500 \ldots 1600^{\circ} \mathrm{C}\right)$.

Рафрінування попутного марганцевого сплаву з підвищеним вмістом фоссрору, який є відходом виробництва малофосффористого марганцевого шлаку, можливо одно стадійним процесом. Його здійснення реалізується за схемою з одночасним протіканням процесів переводу в шлак кремнію і фосфору по реакціям окислювального і обмінного типу і дозволяє істотно збільшити вихід товарного феромарганцю (ФМн70). За цим способом утворюється високо фоссрористий шлак, який згідно з даними експериментальної плавки містить близько $3,5 \%$ фоссфору. Крім того, в одному з варіантів проведення рафрінування за цим способом не потрібно використання додаткових зовнішніх джерел теплової енергії.

У дослідженні [2] встановлено, що дефосфорація марганцевих сплавів в відновлювальних умовах більш інтенсивно проходить при підвищених 
температурах процесу, а в окислювальних - при значно нижчих температурах. Встановлені особливості дефосфорації сплавів на основі марганцю можуть бути використані для обґрунтування раціональної технологічної схеми і встановлення ефективного алгоритму рафрінування супутнього високо фосфрористого марганцевого сплаву від фоссрору. При цьому доцільно проводити рафінування сплаву, в умовах наближених до умов поточного виробництва малофосфористого марганцевого шлаку, при якому температура попутного сплаву становить $1320 \ldots 1350^{\circ} \mathrm{C}$.

Мета дослідження: фрізико-хімічне обґрунтування умов і розробка раціонального алгоритму одностадійного безвідходного способу окислювальноої дефосфорації супутнього високо фосфористого марганцевого сплаву. Такий сплав з підвищеним вмістом фоссрору $€$ відходом існуючого способу виробництва мало фосфористого марганцевого шлаку. Згідно з даними, отриманими від НЗФ, цей сплав має наступний хімічний склад,\%: Mn - 64,6; Si - 0,75; C - 5,8; P - 1,37; Fe - решта, який дещо відрізняється від складів, наведених в $[3,4]$. Це пояснюється деяким розходженням в шихтовці плавок і в умовах ведення даного процесу. Вихід супутнього сплаву при виплавці 1 т шлаку становить біля 96 кг. При цьому , на що вказується в роботі, втрачається до 50кг марганцю на кожну тону мало фосфористого шлаку, що приводить до накопичування марганцевого відходу з високим вмістом фоссоору, який має обмежене застосування.

У складі супутнього фосфористого сплаву є високий вміст вуглецю та кремнію, що свідчить про досить високий відновлювальний потенціал сплаву та можливість його використання при обґрунтуванні умов окислювального рафінування з урахуванням різної хімічної спорідненості елементів сплаву (Mn, P, Si, C, Fe) до кисню. При цьому кінцевою метою може бути не тільки отримання товарного феромарганцю і шлаку з підвищеним вмістом фосффору [1], але й створення безвідходної технології 3 отриманням двох продуктів різного функціонального призначення - шлаку і металу.

Аналіз особливостей фізико-хімічної взаємодії елементів попутного марганцевого сплаву в умовах окислювального рафінування

Термодинамічний прогноз перебігу процесу рафінування марганцевого сплаву від фросфору і інших домішок, а також результати експериментальної перевірки свідчать про неможливість підвищення ефективності процесу, на наш погляд, без створення спеціальних умов по його інтенсифікації. Підвищення показників процесу може бути досягнуто за рахунок проведення окислювального рафінування сплаву шляхом його продувки газоподібним окиснювачем. При цьому негативний ефект, який буде проявлятися в значному підвищенні температури металу і шлаку, необхідно трансформувати в переваги процесу, наприклад шля- хом застосування охолоджувачів плавки (газоподібних, твердих або рідких), кількість і склад яких не знизить, а при створенні певних умов рафінування, підвищить металургійну цінність продуктів рафрінування.

Вибір параметрів окислювального рафінування сплаву, які будуть визначати особливості, механізм і хід дефосфорації, залежить не тільки від початкового складу сплаву і шлакоутворюючих, але і від нових властивостей, які система набуває під впливом на неї факторів зовнішньої дії. Параметри цих впливів на досліджуваний процес можуть бути змінені в залежності від розв'язуваних по ходу процесу технологічних задач з метою регулювання швидкості і напрямку основних реакцій рафрінування сплаву.

Раціональні параметри процесу рафінування потребують створення моделі фрізико-хімічних взаємодій між реагуючими компонентами на основі термодинамічного прогнозу перебігу основних реакцій, оцінки теплової сторони процесу з урахуванням відомих і встановлених особливостей кінетики процесів в заданих умовах ведення плавки. Для умов окислювального рафінування марганцевого сплаву в якості одного з факторів, що визначає його фрізико-хімічні властивості і хід окислення домішок сплаву, доцільно використовувати хімічну спорідненість елементів розплаву до кисню. Оскільки марганець характеризується хімічною спорідненістю до кисню, більшою ніж у заліза [5, 6], провести ефективне видалення фосфору в шлак без значних втрат марганцю шляхом окислювального рафінування практично не можливо.

Фосфор, який міститься в марганцевій руді (концентратах) у вигляді аніону $\mathrm{PO}_{4}{ }^{3-}$, адсорбується гідроксидами и оксидами марганцю, а також представлений фоссратами кальцію [ 7-10]. В процесі виплавки марганцевих фреросплавів фоосфор практично повністю відновлюється не тільки вуглецем , але також кремнієм та марганцем та переходить в марганцеві феросплави [11-14].

В системі $\mathrm{Mn}-\mathrm{P}$ існують наступні фоссфіди марганцю [15, 16]:

$$
\begin{aligned}
& \text { фосфід } \\
& \text { марганцю } \quad \mathrm{Mn}_{3} \mathrm{P} \quad \mathrm{Mn}_{2} \mathrm{P} \quad \mathrm{Mn}_{3} \mathrm{P}_{2} \quad \mathrm{MnP} \\
& \text { вміст } \mathrm{P} \\
& \text { у фоссфіді, \% мас. } 15,82 \quad 21,99 \quad 27,32 \\
& \text { 36,06 }
\end{aligned}
$$

Як показано в роботі [16] більш сильна взаємодія існує між атомами $\mathrm{Mn}$ i P, ніж між атомами $\mathrm{Fe}$ i $P$.

Термохімічні розрахунки основних реакцій, які можуть здійснюватись в умовах окислювального рафрінування марганцевого сплаву з підвищеним вмістом фросфору, виконали з застосуванням пакетy FactSage, що складається з низки модулів інфрормації, бази даних, обчислень та маніпуляцій, які дозволяють отримувати доступ та маніпулювати чистими речовинами та базами даних розчинів [17]. 
Таблиця 1 Змінення величин термодинамічних параметрів основних реакцій при окислювальному рафрінуванні марганцевого сплаву з підвищеним вмістом фросфору.

\begin{tabular}{|c|c|c|c|c|}
\hline \multirow[t]{2}{*}{ № } & \multirow[t]{2}{*}{ Реакція } & \multicolumn{3}{|c|}{ Термодинамічні параметри при $1500^{\circ} \mathrm{C}$} \\
\hline & & $\Delta \mathrm{H}$, кДж & $\Delta \mathrm{S}$, Дж/K & $\Delta \mathrm{G}$, кДж \\
\hline 1 & $2 \mathrm{Mn}_{3} \mathrm{P}+5,5 \mathrm{O}_{2}(\mathrm{~g})=6 \mathrm{MnO}+\mathrm{P}_{2} \mathrm{O}_{5}$ & -3367.019 & -748.907 & -2039.094 \\
\hline 2 & $2 \mathrm{MnP}+3,5 \mathrm{O}_{2}(\mathrm{~g})=2 \mathrm{MnO}+\mathrm{P}_{2} \mathrm{O}_{5}$ & -1957.288 & -511.493 & -1050.334 \\
\hline 3 & $2 \mathrm{Mn}_{2} \mathrm{P}+4,5 \mathrm{O}_{2}(\mathrm{~g})=4 \mathrm{MnO}+\mathrm{P}_{2} \mathrm{O}_{5}$ & -2585.445 & -650.295 & -1432.374 \\
\hline 4 & $5 \mathrm{Mn}+\mathrm{P}_{2} \mathrm{O}_{5}=5 \mathrm{MnO}+2 \mathrm{P}$ & -595.446 & -36.214 & -531.234 \\
\hline 5 & $2 \mathrm{Fe}+\mathrm{O}_{2}(\mathrm{~g})=2 \mathrm{FeO}$ & -476.438 & -99.367 & -300.246 \\
\hline 6 & $\mathrm{Si}+\mathrm{FeO}=\mathrm{Fe}+\mathrm{SiO}_{2}$ & -470.537 & -98.685 & -295.554 \\
\hline 7 & $\mathrm{MnO}+\mathrm{C}=\mathrm{Mn}+\mathrm{CO}(\mathrm{g})$ & 288.379 & 172.248 & -17.042 \\
\hline 8 & $\mathrm{Mn}_{2} \mathrm{P}=2 \mathrm{Mn}+\mathrm{P} \quad 4500^{\circ} \mathrm{C}$ & 209.509 & 45.040 & -5.476 \\
\hline 9 & $\mathrm{Mn}_{3} \mathrm{P}=3 \mathrm{Mn}+\mathrm{P} 2500^{\circ} \mathrm{C}$ & 274.350 & 101.357 & -6.727 \\
\hline 10 & $\mathrm{MnP}=\mathrm{Mn}+\mathrm{P} \quad 3800^{\circ} \mathrm{C}$ & 170.308 & 43.343 & -6.234 \\
\hline
\end{tabular}

Відповідно до даних, представлених в табл. 1, фосфріди марганцю мають високу міцність та їх дисоціація можлива при доволі високій температурі: реакція (8) - 4500 ${ }^{\circ}$; (9) - 2500 ${ }^{\circ} \mathrm{C}$; (10) $3800^{\circ} \mathrm{C}$.

Аналіз термодинамічних умов свідчить, що сутність і механізм фрізико-хімічних перетворень при окислювальному рафінуванні високо фоссоористого марганцю, може бути наступним. Висока термодинамічна міцність фосффідів $\mathrm{Mn}_{2} \mathrm{P}, \mathrm{Mn}_{3} \mathrm{P}$ і $\mathrm{MnP}$ передбачає здійснення насамперед реакцій (1)-(3) 3 утворенням $\mathrm{MnO}$ і $\mathrm{P}_{2} \mathrm{O}_{5}$. Одночасно 3 даними реакціями отримує розвиток реакція окислення марганцю сплаву при взаємодії $3 \mathrm{P}_{2} \mathrm{O}_{5}$ та утворенням шлаку на основі оксидів марганцю, і фоссфору, який розчиняється в залізі, створюючи металеву фазу. У цьому випадку фрізико-хімічна модель окислювального рафрінування марганцевого сплаву 3 підвищеним вмістом фосфору буде визначатись наступними факторами термодинаміки та реальної кінетики:

- одночасне здійснення реакцій, не заборонених термодинамікою 3 швидкістю, які визначаються хімічною спорідненістю елементів до кисню та їх взаємним впливом;

- екзотермічним характером оксислювальновідновлювальних реакцій (окрім реакції окислення вуглецю оксидом заліза), прихід теплової енергії від яких приводить до значного підвищення рівня температур шлаку і металу, що вимагає створення охолоджуючої дії шляхом присадки охолоджувачів плавок;

- високою хімічною активністю марганцю до кисню, що створює умови для інтенсивного окислення марганцю, та «захищає» від окислення фосфор та залізо з формуванням металевої фази;

- формування шлакової фрази на основі оксиду марганцю та матеріалів-охолоджувачів, кількісне співвідношення яких забезпечує в процесі окислювального рафінування необхідну температуру плавлення шлакової фрази, її рідкоплинність і, відповідно, досягнення високих швидкостей рафрінування.

Таким чином, в якості основних положень, які можуть бути використані при обґрунтуванні схеми і встановленні раціональних параметрів окислюва- льного рафрінування сплаву, були прийняті: більш висока в порівнянні з фосфором хімічна спорідненість марганцю до кисню $\left(\Delta G_{M n}<\Delta G_{P}\right)$; екзотермічний характер реакцій окислення марганцю, кремнію, заліза і вуглецю киснем; необхідність охолодження плавки по ходу окисного рафінування сплаву [18]; виключення зі складу охолоджувачів плавки вапна [19]; наближення середньої температури процесу до вихідної температури високо фосфористого сплаву поточного виробництва [20].

Для створення раціонального, за витратами і ефективного по досягаємим результатам, способу дефосфорації марганцевих сплавів проведена аналогія між фрізико-хімічними особливостями переділу розплавів на основі заліза і марганцю. В умовах ведення плавки сталі в кисневому конвертері відбувається окислення надлишкової кількості елементів залізовуглецевого розплаву киснем дуття і оксидами заліза (крім сірки, перехід якої здійснюється по реакції обмінного типу). При цьому обов'язковою умовою ефективної десульфурації $€$ створення основного шлаку. Для кисневоконвертерного процесу характерний також газовий режим його реалізації, в результаті проведення якого отримують сталь і неминучий побічний відхід - шлак, в якому асимільовані шкідливі домішки, в тому числі і фоосфор.

Виробництво ж марганцевих сплавів здійснюється у відновлювальних умовах по ендотермічним реакцій вуглецевотермічного відновлення оксидів марганцю, кремнію та заліза при використанні зовнішніх джерел теплової енергії. При роботі 3 марганцевою сировиною реалізуються кілька технологій з отриманням як мінімум двох видів матеріалів і відповідно двох видів відходу [21]. Ці особливості визначаються тим, що фосфор відомих фросфідів марганцю, що мають досить високу міцність, переходить в значній частині з рудної сировини в сплав і при створенні необхідних умов може асимілюватися шлаком або залишатися в сплаві [22].

3 фрізико-хімічної точки зору реалізація дефосфорації високо фосфористого марганцевого сплаву 3 отриманням додаткової кількості товарного феромарганцю за способом, який аналогічний дефосфорації сталі (феритний спосіб) з використан- 
ням основного шлаку, практично неможливий, оскільки марганець має більшу спорідненість до кисню ніж залізо [5].

При виплавці сталі дефосфорація відбувається за участю шлакової фази, що містить (FeO) в якості окислювача, по відповідній реакції:

$2[\mathrm{P}]+5(\mathrm{FeO})+4(\mathrm{CaO})=\left(4 \mathrm{CaO} \cdot \mathrm{P}_{2} \mathrm{O}_{5}\right)+5[\mathrm{Fe}]$

В умовах виробництва феромарганцю таким окиснювачем може виступати (MnO) по реакції:

$2[\mathrm{P}]+5(\mathrm{MnO})+4(\mathrm{CaO})=\left(4 \mathrm{CaO} \cdot \mathrm{P}_{2} \mathrm{O}_{5}\right)+5[\mathrm{Mn}], \quad$ (2)

Розрахунки показали, що дана реакція в прямому напрямку не відбувається, оскільки марганець має більшу спорідненість до кисню, ніж фосфор. Марганець виступає як відновлювач фосфорного ангідриду, навіть, якщо фосфорний ангідрид пов'язаний з оксидом кальцію:

$\left(4 \mathrm{CaO} \cdot \mathrm{P}_{2} \mathrm{O}_{5}\right)+5[\mathrm{Mn}]=2[\mathrm{P}]+5(\mathrm{MnO})+4(\mathrm{CaO})$

Однак в умовах рафінування сплаву з високим вмістом фосфору реакція окислення фосфору закисом заліза, яка інтенсивно протікає при виплавці сталі, не приведе до суттєвого зменшення вмісту фосфрору в сплаві, оскільки при рафрінуванні фреромарганцю одночасно з цією реакцією з більшою вірогідністю буде відбуватися відновлення фосфорного ангідриду марганцем сплаву за реакцією (3).

В результаті одночасного протікання реакцій (1) і (3) закис заліза буде окислювати марганець з переходом його в шлакову фазу. Таким чи- ном, в умовах виплавки феромарганцю окислювальне рафінування феромарганцю від фосфрору термодинамічно є практично неможливим.

Основна ідея, що визначає в своєму розвитку кінцеві результати рафінування, полягає в створенні умов для переважаючого окислення марганцю, окислення певної частини вуглецю і кремнію 3 утворенням мало фосфрористого шлаку на основі оксидів марганцю і металу на основі заліза і фосфору. Для обґрунтування раціональних фрізикохімічних умов здійснення окислювального рафінування попутного марганцевого сплаву, проведено термодинамічні розрахунки прогнозу поведінки елементів в умовах окислювального рафінування сплаву. Надалі на основі результатів термодинамічного прогнозу і встановлених кінетичних закономірностей процесу необхідно обґрунтування оптимальних умов і пропонування технологічної схеми рафрінування, яка забезпечить реалізацію безвідходного способу окислювального рафінування сплаву.

При розрахунку величин змінення енергії Гіббса для реакцій, що мають місце при окислювальному рафрінуванні попутного марганцевого сплаву, з метою наближення до реальних умов, були враховані величини змінення $\Delta \mathrm{G}$ розчинення в залізі $\mathrm{C}, \mathrm{Si}$, Mn i P за виразами, наведеними в [23]. Результати розрахунків приведені на рис.1.

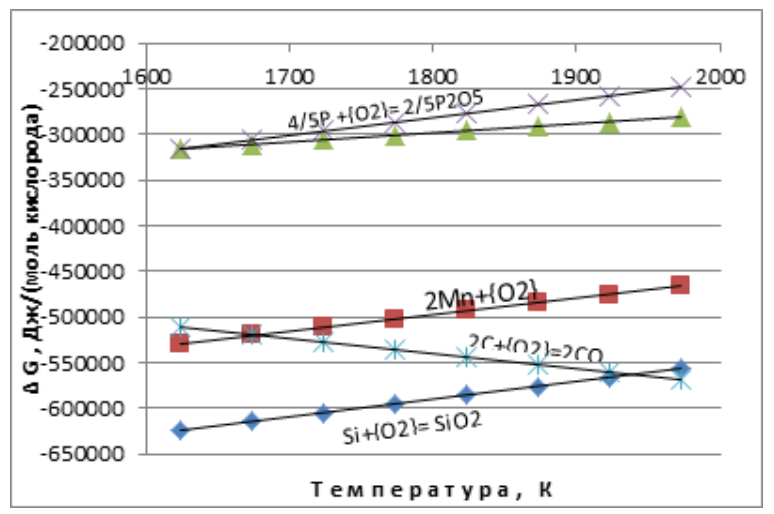

Рис.1 - Вплив температури на змінення енергії Гиббса для реакцій окислення киснем чистих елеменTiв

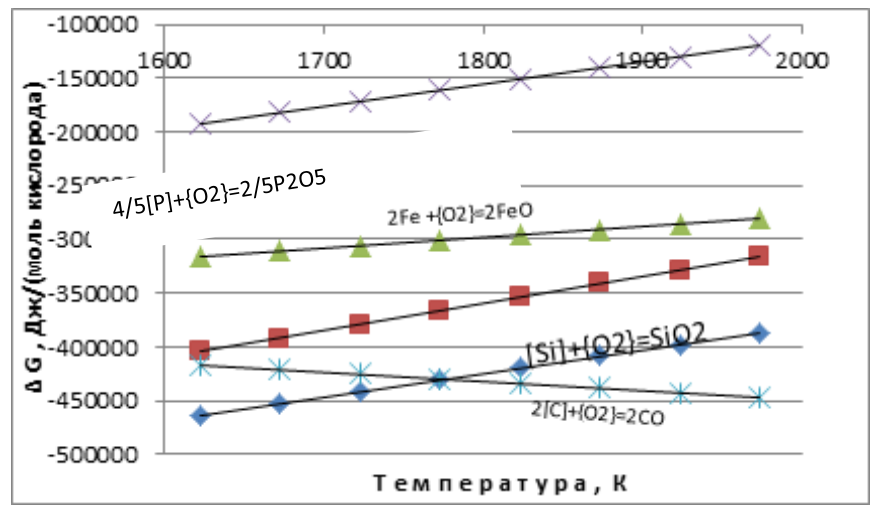

Рис. 2 Вплив температури на змінення енергії Гиббса для реакцій окислення киснем розчинених в залізі елементів 
Приведені значення змінення енергії Гіббса досліджуваних реакцій від температури підтверджує можливість створення необхідних умов, які в процесі окислювального рафінування попутного марганцевого сплаву з високим вмістом фосфору, забезпечать істотну мінімізацію окислення фосфору сплаву і його переходу в шлакову фазу. В цьому випадку фосфрор від окислення будуть «захищати» кремній, марганець, залізо та вуглець металевого сплаву.

Одним 3 найбільш важливих параметрів окислювального рафінування попутного металу є температура процесу. 3 урахуванням того, що температура попутного металу за чинною технології виплавки малофосфористого шлаку становить близько $1350^{\circ} \mathrm{C}$, в якості найбільш раціонального температурного інтервалу випуску продуктів рафінування попередньо був прийнятий інтервал $1400 \ldots 1600^{\circ} \mathrm{C}$ з можливістю наближення температури на випуску до температури вихідного попутного металу. Прийнятий температурний інтервал обґрунтований тим, що при використанні в якості окиснювача тільки повітряного дуття, без додаткового охолодження плавки, кінцева температура може досягати $2000^{\circ} \mathrm{C}$, що потребують використання твердих охолоджувачів плавки.

Іншим, не менш важливим параметром окисного рафінування попутного металу, є кількість і вид окиснювача. Для забезпечення максимального ступеня окислення марганцю і мінімальної фосфору доцільно використовувати поєднання двох видів окиснювачів - газоподібного і твердого. В якості основного окиснювача, необхідного для інтенсифікації процесу, обране повітря. Його використання при рафрінуванні попутного металу обґрунтовано можливістю отримання двох позитивних ефектів синергії: окислення елементів (Mn, Si i C) киснем повітря і охолодження плавки азотом повітря. У разі значного підвищення температури металу i шлаку на випуску їі зниження може бути досягнуто шляхом присадки матеріалів, які є ефективними охолоджувачами, наприклад прокатної окалини. Згідно з даними [24] охолоджуючій ефект окалини приблизно в 4 рази вищий, ніж металобрухту.

Таким чином, при використанні прокатної окалини в процесі окислювального рафінування попутного металу може бути реалізовано ще два позитивних ефекта: охолодження плавки і додаткове окислення домішок сплаву. Сумарний охолоджуючий ефект для варіанта реалізації процесу при $1500^{\circ} \mathrm{C}$ визначається різницею між приходом теплоти від реакцій окислення кремнію ( 17000 кДж/кг кремнію), марганцю ( 3000кДж/кг марганцю), заліза ( 4250кДж/кг заліза) і витратами на нагрів охолоджувачів плавки до заданої температури (окалини, $\mathrm{SiO}_{2}, \mathrm{MgO}$ та ін.), дисоціацію оксидів заліза, які входять до складу окалини: $Q_{\mathrm{Fe} 203}=$

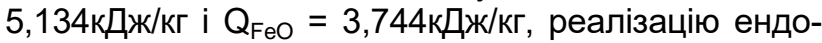
термічної реакції окислення вуглецю сплаву оксидом заліза до СО ( 9500 кДж/кг вуглецю). Згідно з розрахунками питома витрата теплоти при використанні окалини становить близько 4200 кДж/кг окалини. Втрати теплоти в агрегаті конвертерного типу складають в розрахунках $3,5 \%$ від загального приходу теплової енергії. Також були враховані втрати теплоти з газами, що відходять, які утворюються при окислювальному рафрінуванні марганцевого сплаву повітряним дуттям ( $\mathrm{N}_{2}$ і $\left.\mathrm{CO}\right)$.

Для встановлення можливого впливу витрати кисню $\left(\mathrm{O}_{2}\right.$ повітряного дуття та кисень оксидів заліза $\left(\mathrm{FeO}+\mathrm{Fe}_{2} \mathrm{O}_{3}\right)$ і температури процесу на показники окислювального рафінування марганцевого сплаву (склади металу і шлаку) отримані дані, які встановлюють зв'язок між витратою кисню і складами шлакової і металевої фази для умов ведення окислювального рафінування сплаву при різних температурах $1400 \ldots 1900^{\circ} \mathrm{C}$. На рис. 3 - 6 наведені залежності зміни складу шлаку і металу при 1400 і $1500^{\circ} \mathrm{C}$ для умов окислювального рафінування сплаву з використанням повітряного дуття.

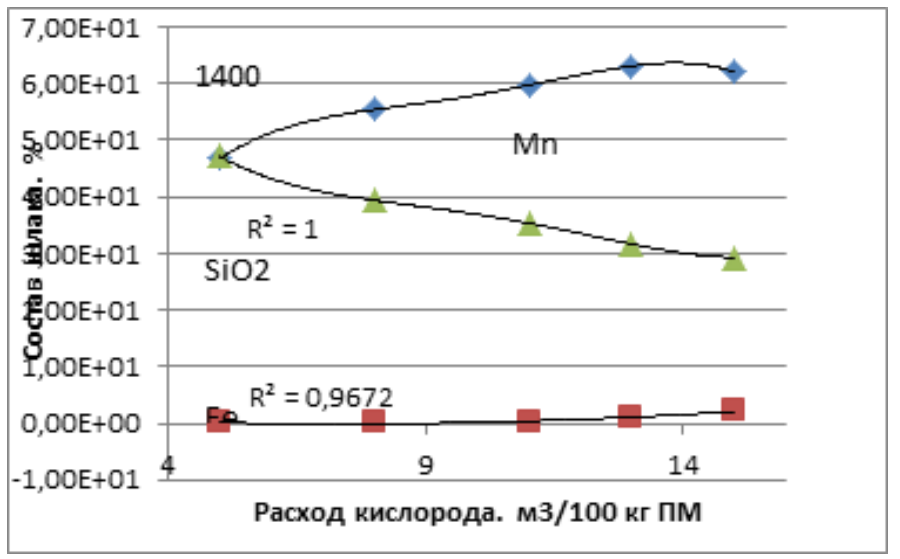

Рис. 3 - Склад шлакової фрази при зміненні витрати кисню при рафрінуванні супутнього марганцевого металу $-1400^{\circ} \mathrm{C}$

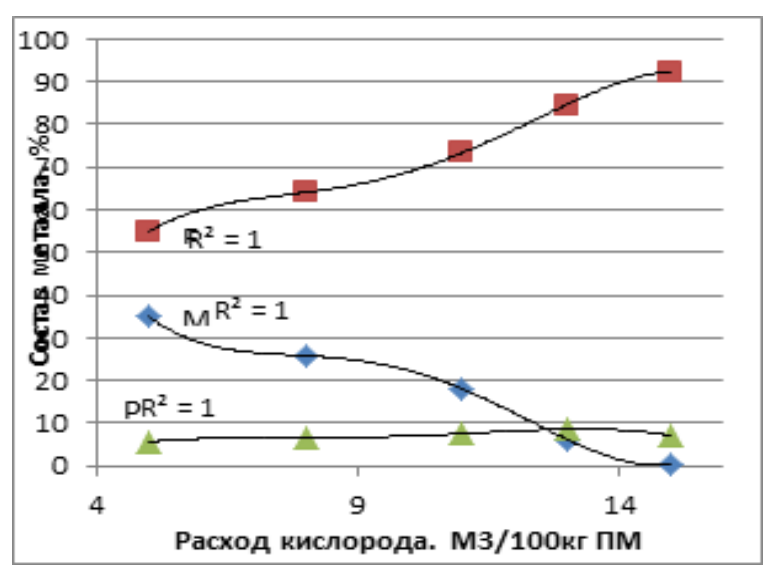

Рис. 4 - Вплив витрати кисню на склад металевої фрази при рафінуванні супутнього марганцевого металу $-1400^{\circ} \mathrm{C}$ 


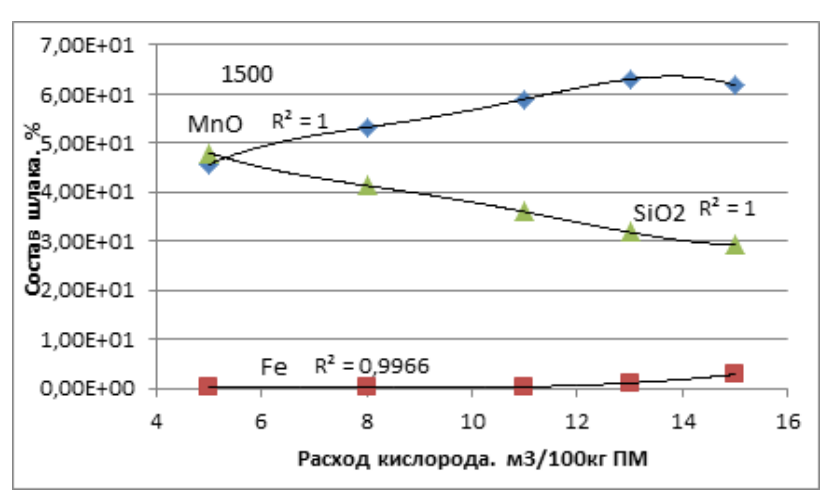

Рис. 5 - Вплив витрати кисню на змінення складу шлакової фрази при окислювальному рафрінуванні супутнього марганцевого металу $1500^{\circ} \mathrm{C}$

Аналіз, наведених на рис. 3-6 залежностей складів металевої і шлакової фраз від витрати кисню і температури процесу, дозволяє припустити, що при використанні на весь процес рафінування високо фосфористого металу $13 \mathrm{~m}^{3}$ кисню забезпечується досягнення поставлених завдань отримання марганцевого низько фоосфористого шлаку і металевої фрази на основі заліза і фросфору. При використанні в якості окиснювача тільки повітряного дуття витрата повітря, який забезпечить надходження в ванну $13 \mathrm{~m}^{3}$ кисню становить близько 61,9 $\mathrm{m}^{3}$ (кисню - $13 \mathrm{~m}^{3} \mathrm{i}$ азоту - 48,9 $\mathrm{m}^{3}$ ). Зниження витрати кисню нижче $13 \mathrm{~m}^{3}$ на 100 кг сплаву призводить до зменшення вмісту в шлаковій фразі (MnO), підвищення витрати повітря вище $13 \mathrm{~m}^{3}$ в досліджуваному інтервалі температур $\left(1400 \ldots 1900^{\circ} \mathrm{C}\right)$ - до зниження вмісту в шлаку (MnO) за рахунок підвищення в ньому вмісту (FeO). Інтенсивність утворення (FeO) буде посилюватися з пониженням вмісту в металі вуглецю, кремнію і марганцю. У той же час, зниження температури на $100^{\circ} \mathrm{C}$ призводить до зменшення повноти переходу марганцю в шлак на 0,8\%. Підвищення температури процесу на $100^{\circ} \mathrm{C}$ збільшує вміст фосфору в шлаку на 0,7\% при збільшення в ньому вмісту $\mathrm{FeO} \sim$ на 0,9\%.

Використання повітряного дуття при проведенні окислювального рафінування високо фосфористого марганцевого сплаву на мало фосфористий марганцевий шлак, на що вказують результати розрахунків, призводить до суттєвого підвищення температури металу і шлаку до $\sim 2000^{\circ} \mathrm{C}$ за рахунок екзотермічних реакцій окислення домішок сплаву марганцю, вуглецю, кремнію і заліза (крім ендотермічної реакції окислення вуглецю оксидом заліза). Тому з метою обґрунтування виду і кількості присадок - охолоджувачів для компенсації надлишку теплоти проведена оцінка теплової сторони процесу окислювального рафрінування високо фосфористого металу.

У розрахунках з метою зменшення приходу теплоти від реакцій окислення домішок сплаву киснем повітряного дуття і зниження витрати охоло-

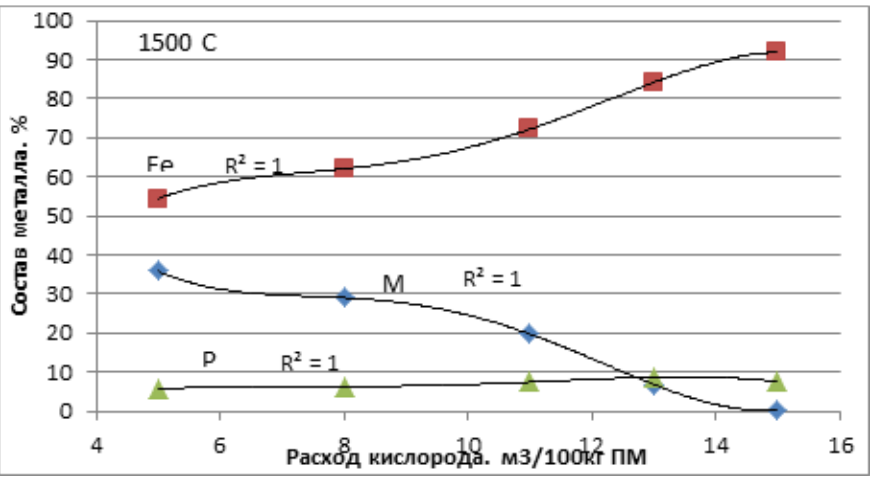

Рис. 6 - - Вплив витрати кисню на змінення складу металевої фрази при окислювальному рафінуванні супутнього марганцевого металу $-1500^{\circ} \mathrm{C}$

джувачів плавки змінювали співвідношення окиснювачів при дотриманні сталості загальної витрати кисню на рівні $13 \mathrm{~m}^{3} / 100$ кг сплаву. Так витрата окалини збільшували за наступним алгоритмом:

$17 \kappa г\left(\mathrm{FeO}-10,12 \kappa г ; \mathrm{Fe}_{2} \mathrm{O}_{3}-6,61 \kappa г\right) \rightarrow 20 \kappa г(\mathrm{FeO}$ $\left.-11,9 \kappa г ; \mathrm{Fe}_{2} \mathrm{O}_{3}-7,78 \mathrm{\kappa} \Gamma\right) \rightarrow 25 \mathrm{\kappa} \Gamma(\mathrm{FeO}-14,88 \mathrm{\kappa} \Gamma ;$ $\left.\mathrm{Fe}_{2} \mathrm{O}_{3}-9,73 \kappa г\right) \rightarrow 30\left(\mathrm{FeO}-17,85 \kappa r ; \mathrm{Fe}_{2} \mathrm{O}_{3}-\right.$ 11,67кг) при відповідному зниженні витрати повітряного дуття в м ${ }^{3}: 47,8\left(10,04 \mathrm{M}^{3} \mathrm{O}_{2}\right) \rightarrow 45,3(9,52$ $\left.\mathrm{M}^{3} \mathrm{O}_{2}\right) \rightarrow 41,17\left(8,65 \mathrm{~m}^{3} \mathrm{O}_{2}\right) \rightarrow 37,0\left(7,77 \mathrm{~m}^{3} \mathrm{O}_{2}\right)$.

Вибір охолоджувачів плавки обґрунтовується наступними факторами: ефективним охолодженням при мінімізації кількості охолоджувачів, їх доступністю; забезпеченням умов, що виключають розвиток реакції переводу фосфору в шлакову фразу; забезпеченням заданого складу малофосфористого шлаку за вмістом (MnO). Присутність у шлаковій фазі вапна або вапняку значно підвищує вірогідність розвитку процесу переходу фосфору в шлак.

При оцінці теплової сторони процесу в якості основних охолоджувачів плавки обрані магнезит $(\mathrm{MgO})$ і кремнезем $\left(\mathrm{SiO}_{2}\right)$, витрата яких на 100 кг сплаву залишалась постійною - 4 кг MgO і 30 кг $\mathrm{SiO}_{2}$. ІІх вибір обумовлений необхідністю створення шлакової фази системи $\mathrm{MnO}-\mathrm{SiO}_{2}-\mathrm{MgO}-\mathrm{FeO}$, температура плавлення якої повинна бути менше початкової температури рафінування попутного металу $\left(<1350^{\circ} \mathrm{C}\right)$ або близькою до неї.

На підставі аналізу попередніх розрахунків теплових балансів, за якими також розраховувалося можливе підвищення температури процесу, проводили коригування плавки шляхом зміни співвідношень витрат повітряного дуття, прокатної окалини і охолоджувачів. Для створення охолоджуючого ефекту, необхідного для компенсації надлишку теплоти $(\Delta Q)$ при використанні двох видів окиснювачів (повітря і прокатної окалини), в якості додаткового охолоджувача може бути використаний металевий лом (сталева січка з вмістом вуглецю 0,015\%), кількість якої розраховується за такими виразами :

$$
\begin{aligned}
& \Delta Q=M_{\text {охл }} \cdot \mathrm{Cp}_{\text {охл }} \cdot\left(\mathrm{T}_{\text {кін }}-\mathrm{T}_{\text {поч }}\right) \\
& \mathrm{M}_{\text {охл }}=\Delta \mathrm{Q} / \mathrm{Cp}_{\text {охл }} \cdot\left(\mathrm{T}_{\text {кін }}-\text { Тпоч }\right),
\end{aligned}
$$


де $\mathrm{Cp}_{\text {охл }}$ - питома теплоємність охолоджувача $\left(\mathrm{Cp}_{\mathrm{Fe}} \quad=60 \kappa Д ж / к г \cdot г р а д\right)$.

Для розрахунку кінцевої температури металу та шлаку після проведення окислювального рафрінування високо фоосфористого металу використовували балансове рівняння:

$0,965 \mathrm{Q}=\left(\mathrm{M}_{\text {ме }} \mathrm{C}_{\mathrm{p}, \mathrm{ме}}+\mathrm{M}_{\text {шл }} \mathrm{C}_{\mathrm{p} \text { шл }}\right)\left(\mathrm{T}_{\text {кін }}-\mathrm{T}_{\text {поч }}\right)+$ $\mathrm{V}_{\mathrm{N} 2}\left(1,5777 \mathrm{~T}_{\text {кін }}-190,5\right)+\mathrm{V}_{\mathrm{co}}\left(1,6009 \mathrm{~T}_{\text {кін }}-191,73\right)$

$T_{\text {кін }}=\left(0,965 Q+T_{\text {поч }}\left(M_{\text {ме }} C_{p, \text { ме }}+M_{\text {шл }} C_{p, \text { шл }}\right)+\right.$ $\left.190,5 \mathrm{~V}_{\mathrm{N} 2}+191,73 \mathrm{~V}_{\mathrm{co}}\right) /\left(\mathrm{M}_{\mathrm{me}} \mathrm{C}_{\mathrm{p}, \mathrm{мe}}+\mathrm{M}_{\text {шл }} \mathrm{C}_{\mathrm{p} \text {,шл }}\right.$ $\left.+1,5777 \mathrm{~V}_{\mathrm{N} 2}+191,78 \mathrm{~V}_{\mathrm{co}}\right)$

Результати теплової оцінки процесу окислювального рафрінування високо фоссрористого металу наведені у вигляді графічних залежностей на рис. 7 і 8. Так на рис. 7 показано, як впливає зміна витрати повітряного дуття (без твердого окислювача) на загальний прихід теплової енергії і на кількість охолоджувача (Fe), що присаджується, необхідного для компенсації надлишку теплоти від реакцій окислення домішок сплаву.

Згідно з даними, наведеними на рис. 7, при витраті повітряного дуття $61,9 \mathrm{~m}^{3}\left(\mathrm{O}_{2}-13 \mathrm{~m}^{3} \mathrm{i} \mathrm{N}_{2}\right.$ $\left.48,9 \mathrm{~m}^{3}\right)$, для компенсації загального приходу теплоти необхідно присадити близько 114 кг охолоджувача. Збільшення частки твердого окиснювача (окалини) при збереженні загальної витрати кисню 13м ${ }^{3}$ призводить до зменшення витрати повітряного дуття і зниження витрати охолоджувача для компенсації загального приходу теплоти. Так, для варіанту 3 присадкою на 100 кг сплаву 17 кг окалини при подачі 47,8 м³ повітря для компенсації загального приходу теплоти необхідно присадити близько 80,7 кг охолоджувача (Fe). Аналіз результатів оцінки теплової сторони окислювального рафінування високо фосфористого супутнього металу дозволяє стверджувати, що збільшення витрат повітряного дуття знижує витрату твердого окиснювача і істотно збільшує витрату охолоджувачів плавки.

На рис. 8 наведені узагальнені дані розрахунку показників теплової сторони процесу окислювального рафрінування марганцевого сплаву, які показують вплив витрати повітряного дуття на прихід теплоти від окислення домішок сплаву $(\mathrm{Mn}, \mathrm{Si}, \mathrm{Fe}$, P і C), витрата теплоти на нагрів охолоджувачів і шлакоутворюючих, дисоціацію оксидів заліза, що містяться в прокатній окалині, втрати теплоти в агрегаті і з винесеними газами, що відходять і на кількість охолоджувача $\left(Q_{\mathrm{Fe}}\right)$, необхідного для компенсації загального приходу теплоти.

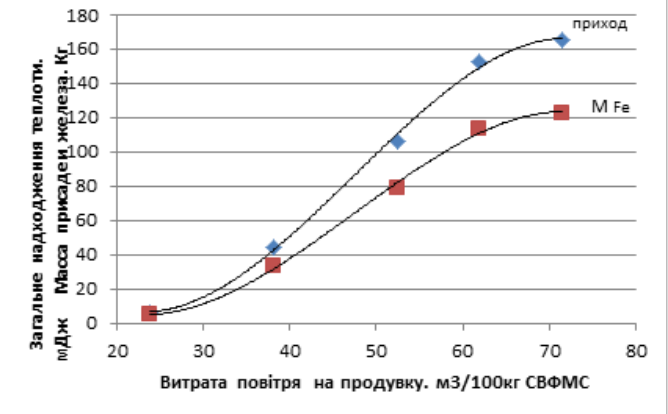

Рис. 7 Вплив витрати повітряного дуття на загальний прихід теплоти і кількість охолоджувача (Fe). Продувка сплаву повітрям без використання окалини з присадкою шлакоутворюючих $\left(\mathrm{SiO}_{2}-\right.$ 30кг и $\mathrm{MgO}$ - 4кг)

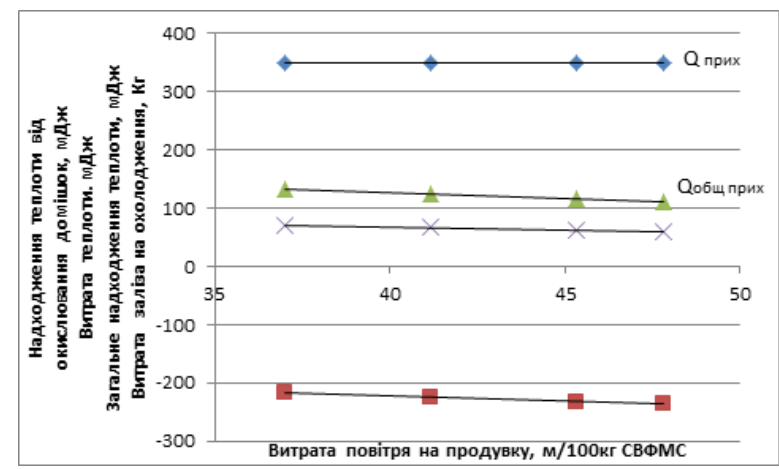

Рис.8 Вплив витрати повітряного дуття на узагальнені дані розрахунку показників теплової сторони процесу окислювального рафінування марганцевого сплаву

Встановлено, що в інтервалі зміни температури від 1300 до $1900^{\circ} \mathrm{C}$ при витраті кисню $13 \mathrm{~m}^{3}$ і застосуванні в якості охолоджувачів 4кг $\mathrm{MgO}$ і 30кг $\mathrm{SiO}_{2}$ вміст MnO в шлаку практично не змінюється і становить в\%: при $1300^{\circ} \mathrm{C}-63,2 ;$ при $1900^{\circ} \mathrm{C} \sim 61,9$. Зміна вмісту інших компонентів і елементів шлакової і металевої фраз прі1300 і $1900^{\circ} \mathrm{C}$ відповідно становить: $\mathrm{SiO}_{2}$ - 31,7 і 32,0; (P) - 0,117 і 0,00225; аналогічні дані одержані по складу металевої фрази: $\mathrm{Mn}$ - $(4,05 \div 6,77$ і $(4,31-6,15) ; \mathrm{P}-(5,92 \div 6,77)$ $(6,15-7,16)$; C - $(0,273-0,331)$ i $(0,00579 \div 0,00677)$; $\mathrm{Fe}-(88,0-89,7)$ i $(88,7-89,5)$.

На підставі аналізу отриманих даних значного впливу температури на склади шлакової і металевої фази при постійній витраті кисню не виявлено. Необхідна температура випуску розплавів шлаку та металу визначається температурою плавлення мало фосфористого марганцевого шлаку, яка становить близько $1400^{\circ} \mathrm{C}$, що значно вище температури плавлення залишків металевої фрази на основі заліза, яка містіть 4-6\% фоссрору. 
Можна очікувати, що найбільш раціональною температурою процесу окислювального рафінування, при якій будуть вирішені поставлені завдання отримання мало фосфористого марганцевого шлаку і металу на основі заліза і фосфору є температура $1500^{\circ} \mathrm{C}$. Проведення процесу окислювального рафінування марганцевого сплаву при цій температурі дозволить також мінімізувати і витрати твердого окиснювача і охолоджувачів плавки. Згідно термодинамічного прогнозу проведення процесу при цій температурі забезпечує отримання мало фосфористого шлаку наступного складу\% мас.: $\mathrm{MnO}$ - 61,8; $\mathrm{FeO}-0,95 ; \mathrm{SiO}_{2}-31,79$ та $(\mathrm{P})-$ 0,033 , а також металу: C - 0,27; Si $-3,08 \cdot 10^{-5} ; \mathrm{P}$ 7,49; $\mathrm{Mn}-6,84$ и $\mathrm{Fe}-84,19$. Зниження температури на випуску з наближенням її до вихідної температурі сплаву ( $\left.1350^{\circ} \mathrm{C}\right)$ після проведення окислювального рафінування може бути досягнуто за рахунок використання в якості додаткового охолоджувача присадок мало фоосфористого шлаку (некондиції).

Таким чином, результати термодинамічного прогнозу поведінки елементів супутнього сплаву в окислювальних умовах і оцінки теплової сторони процесу підтверджують можливість створення безвідходної технологічної схеми проведення рафінування супутнього високо фосфористого марганцевого сплаву.

На основі аналізу літературних джерел з рафінування марганцевих сплавів можна зробити висновок про практичну відсутність технологій окислювального рафінування, які можуть бути адаптовані до умов промислового виробництва. Тому при обмеженому обсязі даних про фрізико-хімічні особливості окислювального рафінування марганцевих сплавів, що містять підвищену кількість фосфору, певний інтерес представляє вивчення процесу отримання шлакового розплаву на основі оксидів ванадію, елемента, з високою хімічною спорідненістю до кисню. Згідно термодинамічними розрахунками теплопродуктивність реакції окислення 1г ванадію в інтервалі температур $1300 . .1600^{\circ} \mathrm{C}$ киснем становить понад 14 кДж. Теплопродуктивність ж окислення 1г марганцю - близько 7 кДж, що приблизно в два рази нижче реакції окислення ванадію. Величини зміни енергії Гіббса при $1500^{\circ} \mathrm{C}$ для реакцій окислення киснем ванадію і марганцю, які становлять відповідно в кДж - 857,69 і - 499,89, характеризують високу хімічну активність цих елементів. Термодинамічні величини констант відповідних реакцій складають: $\mathrm{K}_{\mathrm{V}}=1,86 \cdot 10^{25}$ i $\mathrm{K}_{\mathrm{Mn}}=5,34 \cdot 10^{14}$, що свідчить про близькість швидкісних можливостей цих реакцій.

Технологія отримання ванадієвого шлаку реалізується шляхом продувки ванадієвого чавуну киснем через водоохолоджувальну фурму. Для зниження температури металу і шлаку до заданої на випуску використовують флюс і прокатну окалину. [25-29]. При цьому, окалина виконує дві функції: додатково окислює ванадій і інші домішки чавуну і охолоджує чавун, нагрітий за рахунок теплової енергії реакцій їх окислення до необхідної температури на випуску. Вагові співвідношення фрлюсу і окалини визначаються з теплового балансу плавки. Значний вміст окалини в суміші, що складається з окалини і фрлюсу ( 90\% окалина і 10\% флюс), є причиною зниження продуктивності даного способу.

До складу фрлюсу входять, мас.\%: $\mathrm{SiO}_{2}-40 \div$ $50 ; \mathrm{Al}_{2} \mathrm{O}_{3}-25 \div 30 ; \mathrm{Fe}_{2} \mathrm{O}_{3}-2,5 \div 4,0 ; \mathrm{Na}_{2} \mathrm{O}+\mathrm{K}_{2} \mathrm{O}-$ $15 \div 25$; $\mathrm{CaO}-1,2 \div 1,6$; $\mathrm{MgO}$ - 0,4 та інш. при співвідношенні компонентів в окислювачі - охолоджувачі, мас.\%: окалина - $88 \div 93$, флюс $7-12$. Значний вміст окалини в окислювачі-охолоджувачі та оксидів лужних елементів у флюсі при їх позитивному впливі на одержання рідкоплинної шлакової фази підвищує їх агресивну дію на футеровку агрегату, зменшуючи її стійкість.

Відповідність способів окислювального рафрінування сплавів на основі ванадію та марганцю ґрунтується на тому, що розглянуті елементи $є$ досить активними до кисню Таким чином, можна стверджувати, що спосіб отримання шлакового розплаву на основі оксидів ванадію $є$ найбільш близьким за фрізико-хімічною сутністю і результатам, що досягається.

Завданням технологічного характеру при розробці способу окислювального рафінування високо фоссфористого марганцевого сплаву $€$ збільшення ступеню наскрізного вилучення марганцю 3 вихідної марганцевої сировини за рахунок отримання додаткової кількості малофосфористого марганцевого шлаку. Зниження температури металу та шлаку, яка може значно підвищитися за рахунок теплоти екзотермічних реакцій, досягається присадкою по ходу процесу охолоджувачівокислювачів та охолоджувачів-фрлюсів.

Встановлено, що в способі виробництва малофоссрористого марганцевого шлаку з супутнього металу продувку його розплаву з температурою $1300 \div 1350^{\circ} \mathrm{C}$ доцільно проводити з використанням повітря. В якості охолоджувача використовувати азот повітряного дуття, а в якості охолоджувача-окислювача - залізну окалину. В якості охолоджувача-флюсу - брикетовану суміш, що складається з двох компонентів із розрахунку на 100кг супутнього марганцевого розплаву: $\mathrm{SiO}_{2}-28-32 \kappa г$, $\mathrm{MgO}$ - 3-5кг; в якості охолоджувача-окислювача 17-20кг окалини на 100кг супутнього марганцевого розплаву. При цьому окислювання домішок сплаву забезпечуються киснем повітря та окалини при за-

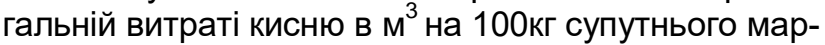
ганцевого розплаву відповідно 9,0-11,0 та 2,0-- 4,0.

Експериментальна оцінка ефективності рафінування попутного марганцевого сплаву в окислювальних умовах 3 використанням охолоджувачів плавки.

Дослідну плавку проводили на високотемпературній моделі 30 кг агрегату конвертерного типу 3 магнезитовою футеровкою. В якості об'єкту рафінування використано супутній марганцевий метал, який отримано в умовах НФЗ при виробництві ма- 
ло фосфрористого марганцевого шлаку в кількості 30 кг наступного складу в \% мас.: $\mathrm{Mn}-50,00 ; \mathrm{Fe}-$ 42,00; C - 3,50; $\mathrm{Si}-0,20 ; \mathrm{P}-4,30$.

В якості газоподібного окислювача використовували повітря, яке від компресора вводилось в рідкий сплав через верхню продувну двосоплову фурму, яка охолоджувалась проточною водою. Питома витрата повітря на одне сопло складала $0,55 \mathrm{~m}^{3} /$ хв. Внутрішні діаметри сопел продувної фрурми дорівнювали 3,8 мм. Температура супутнього металу, який розплавляли в індукційній печі ЛПЗ67 складала $1320^{\circ} \mathrm{C}$. Футерування плавильного агрегату перед випуском в нього дослідного супутнього металу розігрівалась до $\sim 1200^{\circ} \mathrm{C}$. Розташування фурми над рівнем спокійного металу складало 76 мм (20калібрів). Час продування - 13 хвилин. Загальний час процесу окислювального рафрінування супутнього марганцевого металу з триразовою присадкою флюсу та окалини (3.0,5 хв.) становив 14,5 хв. Загальна кількість окалини складала 5,1кг. Алгоритм введення присадок: перша - 1,5кг окалини, 2,65кг кварциту, 0,35кг магнезиту; друга - 2,1кг окалини, 3,7кг кварциту, 0,49кг магнезиту; третя - 1,5кг окалини, 2,65кг кварциту, 0,35 кг магнезиту.

Присадки фрлюсів та окалини здійснювали з використанням брикетів на їх основі (діаметр - 3,2

Табл. 2 Результати експериментального високотемпературного моделювання окислювального рафрінування високо фоссрористого металу

\begin{tabular}{|c|c|c|c|c|c|c|c|c|c|c|c|}
\hline \multirow{3}{*}{$\begin{array}{l}\text { № } \\
\text { пл. }\end{array}$} & \multicolumn{10}{|c|}{ Вид продукту окислювального рафінування СМ } & \multirow{3}{*}{$\begin{array}{l}\mathrm{T},{ }^{\circ} \mathrm{C} \text { на } \\
\text { випуску, }\end{array}$} \\
\hline & \multicolumn{5}{|c|}{ Малофосфористий марганцевий шлак, \%мас. } & \multicolumn{5}{|c|}{ Металева фраза (феросоосфор),\%мас. } & \\
\hline & $\mathrm{MnO}$ & $\mathrm{FeO}$ & $\mathrm{SiO}_{2}$ & $\mathrm{MgO}$ & $\mathrm{P}_{2} \mathrm{O}_{5}$ & $\mathrm{Fe}$ & $\mathrm{Mn}$ & $\mathrm{P}$ & C & Si\% & \\
\hline 1 & 61,30 & 1,58 & 31,80 & 5,30 & 0,01 & 86,60 & 6,99 & 6,38 & 0,026 & 0,002 & 1530 \\
\hline $2^{*}$ & 63,8 & 1,25 & 29,7 & 4,95 & 0,02 & 85,40 & 6,57 & 6,30 & 0,022 & 0,003 & 1410 \\
\hline
\end{tabular}

*Плавку №2 проведено з додатковим охолодженням за рахунок присадки 5 кг малофросфористого марганцевого шлаку (60-65\% $\left.\mathrm{MnO} ; 28-30 \% \mathrm{SiO}_{2} ; 0,02-0,04 \% \mathrm{P}_{2} \mathrm{O}_{5} ; 0,5-0,8 \% \mathrm{FeO} ; 4,0-6,0 \% \mathrm{CaO}\right)$.

Температура металу перед введенням на поверхню розплаву першої порції окалини та флюсів становила $\sim 1425^{\circ} \mathrm{C}$; перед введенням на поверхню розплаву другої порції $1495^{\circ} \mathrm{C}$; третьої $1550^{\circ} \mathrm{C}$. Температура по закінченню процесу окислювального рафрінування перед випуском шлаку та металу становила біля $1595^{\circ} \mathrm{C}$. В результаті реалізації способу рафрінування 30 кг супутнього металу (відходу виробництва мало фоссрористого шлаку) в лабораторних умовах з застосуванням високотемпературної моделі конвертерного типу отримано мало фосфоористого шлаку в кількості 25,6 кг (плавка №1) та металу, близькому за складом до ферофроссрору в кількості 17,4 кг. При використанні додаткового охолодження плавки присадкою 5 кг мало фоосфористого марганцевого шлаку отримано 30,4 кг шлаку. Отримані результати свідчать про доцільність використання в промислових умовах рафрінування високо фосфористого марганцевого сплаву в окислювальних умовах з використанням в якості окислювачів повітря та прокатної окалини, в якості охолоджувачів - кварциту та магнезиту, при необхідності сталевого лому.

Обговорення результатів. Діапазони витрат повітря, окалини та присадок фрлюсів, які присаджуються по ходу продувки в указаних межах, в см; товщина - 3,5см). Замір температури металевого розплаву здійснювався з використанням термопари BP5/20, що занурюється в розплав: перший замір - після випуску супутнього металу в лабораторний агрегат, наступні - перед введенням фрлюсу та окалини, останній замір температури проводився через 0,5 хвилини після закінчення продувки.

Введення присадок на поверхню рідкої ванни здійснювалось $з$ припиненням продування металевої ванни повітрям на 0,5 хв. Перша порція присаджувалась на поверхню металевої ванни після продування на протязі 2 хвилин; друга - після продування на протязі 4 хвилин; третя 'після продування на протязі ще 4 хвилин.

Після присадки останньої частки присадок продувка здійснювалась на протязі 3 хвилин, що необхідно для підтримки шлаку в рідкоплинному стані, реалізації заключного періоду окислювання марганцю киснем повітря та окалини, підвищення температури шлаку та залишків металу до температури випуску $\left(\sim 1550 \ldots 1600^{\circ} \mathrm{C}\right)$ та усереднення металевої та шлакової фаз за хімічним складом і температурою. По закінченню процесу відбирались проби шлаку та металу, в яких визначали на хімічний склад.

цілому визначаються фрізико-хімічними закономірностями утворення шлакової фази на основі оксидів марганцю, кремнезему, магнезиту та інш. Для обґрунтування раціональної кількості охолоджувачів (магнезиту, кварциту, металевого лому), окрім аналізу фрізико-хімічних особливостей процесу, проаналізовано його теплову сторону, що дало можливість досягати зниження температури металу та шлаку до оптимального значення.

На основі аналізу особливостей теплового балансу процесу визначена найбільш раціональна витрата окислювачів (кисню повітря та окалини), яка повинна становити $11-15 \mathrm{~m}^{3} / 100$ кг супутнього металу. Зниження загальної витрати кисню на 100кг супутнього металу нижче $11 \mathrm{~m}^{3}$, що відповідає приблизно $9 \mathrm{~m}^{3}$ в повітрі та $2 \mathrm{~m}^{3}-$ в окалині, приведе до зменшення окислювального потенціалу i, відповідно, до зниження вмісту $\mathrm{MnO}$ у шлаку та до збільшення в металевій фразі вмісту Mn. Зниження частки окалини, що використовується як для окислювання елементів розплаву, так і для його охолодження, приводить також до зменшення ефректу охолодження. Підвищення загальної витрати кисню більше $15 \mathrm{~m}^{3}$, що приблизно відповідає $11 \mathrm{~m}^{3}$ в повітрі та $4 \mathrm{~m}^{3}$ - в окалині, на100кг супутнього металу приведе до зменшення вмісту MnO у 
шлаку, за рахунок одночасного підвищення в ньому FeO та значно підвищить температуру на випуску металу та шлаку, що також потребує збільшення витрати матеріалів для охолодження плавки. Підвищення витрат флюсу $\left(\mathrm{SiO}_{2}, \mathrm{MgO}\right)$ призведе до зростання температури плавлення шлаку та знизить вміст $\mathrm{MnO}$ у шлаку. Підвищення присадки окалини понад 20кг на 100 кг супутнього марганцевого металу зменшить витрату кисню повітря, що суттєво зменшить інтенсивність окислювання марганцю та інших елементів металевого розплаву і значно підвищить час процесу окислювання.

Для обґрунтування раціональних інтервалів присадок компонентів - флюсу (кварциту та магнезиту) необхідно враховувати ефект охолоджування від використання окалини, магнезиту та кварциту. Їх раціональні діапазони витрат становлять: кварциту 28-32кг, магнезиту 3-5кг на 100кг супутнього металу. Використання кварциту та магнезиту необхідно для утворення шлакової системи $\mathrm{MnO}-$ $\mathrm{SiO}_{2}-\mathrm{MgO}$ з необхідною температурою плавлення і в'язкістю. Зменшення вмісту $\mathrm{SiO}_{2}$ у шлаку цієї системи нижче 28\% значно підвищує температуру плавлення шлаку, а підвищення понад $32 \%$ також приводить до підвищення температури плавлення шлаку та зниження його рідкоплинності, що приведе до зниження інтенсивності рафінування сплаву. Згідно з діаграмою стану системи $\mathrm{MnO}-\mathrm{SiO}_{2}$ температура плавлення шлаку за рахунок утворення $\mathrm{Mn}_{2} \mathrm{SiO}_{4}$ при $28 \% \mathrm{SiO}_{2}$ становить $1315^{\circ} \mathrm{C}$.

В процесі продувки розплаву повітрям можливий перехід $\mathrm{MgO}$ з футеровки агрегату у шлак. Згідно діаграми стану $\mathrm{MgO}-\mathrm{MnO}-\mathrm{SiO}_{2}$ додавання $\mathrm{MgO}$ вище 5\% приводить до суттєвого підвищення температури шлаку і зниження його в'язкості. Присадка $\mathrm{MgO}$ нижче $3 \%$ не $є$ ефективною для отримання рідкоплинної шлакової фази, що призведе до зменшення інтенсивності реакції окислювання марганцю на межі шлак - метал та зниження ефекту охолодження шлаку та металу. Слід відзначити, що підвищення в шлаковій фазі вмісту $\mathrm{SiO}_{2}$ та $\mathrm{MgO}$ приведе також до зниження в ній вмісту MnO.

Термодинамічними розрахунками встановлено, що при загальній витраті кисню $10 \mathrm{~m}^{3} / 100 к г$ супутнього металу $\left(7 \mathrm{~m}^{3} \mathrm{O}_{2}\right.$ повітря $+3 \mathrm{~m}^{3} \mathrm{O}_{2}$ окалини) вміст $\mathrm{MnO}$ у шлаку становить $\sim 58 \%$, а при витраті $13 \mathrm{~m}^{3} / 100 \kappa г$ супутнього металу $\left(9,1 \mathrm{~m}^{3}\right.$ повітря + $3,9 \mathrm{M}^{3}$ окалини) - приблизно $\sim 62 \%$, що $є$ максимально можливою для даних умов. Необхідно відмітити, що подальше підвищення витрати кисню призводить до значного підвищення в шлаковій фазі вмісту $\mathrm{FeO}$, що приводить до зниження в ньому вмісту $\mathrm{MnO}$. Так при витраті $15 \mathrm{~m}^{3} / 100 \kappa г$ $\left(11 \mathrm{~m}^{3}\right.$ повітря $+4 \mathrm{~m}^{3}$ окалини) вміст $\mathrm{FeO}$ в шлаковій фазі становить біля 8\%. Значення зміни енергії Гіббса в Дж/моль кисню становить для реакцій окислювання відповідних елементів киснем, розчиненим у розплаві, при $1600^{\circ} \mathrm{C}$ : фосорору (-150000); заліза (-300000); марганцю (-350000); кремнію (-420000); вуглецю (-430000). Таким чином, фракторами, що забезпечують отримання марганцево- го шлаку з мінімальним вмістом в ньому фоссрору, $€$ захисна від окислювання фосфору киснем роль $\mathrm{C}, \mathrm{Si}, \mathrm{Mn}$ та Fe металевого розплаву, яка забезпечується більш високою хімічною спорідненістю цих елементів до кисню в реальних умовах здійснення процесу, що розглядається.

Зниження температури, яка підвищується за рахунок теплоти екзотермічних реакцій окислювання $\mathrm{C}, \mathrm{Si}, \mathrm{Mn}$ та Fe розплаву киснем повітря, досягається поетапною присадкою компонентів флюсу: кварциту $\left(\mathrm{SiO}_{2}\right)$, магнезиту $(\mathrm{MgO})$ та прокатної окалини ( $\left.\mathrm{FeO}, \mathrm{Fe}_{2} \mathrm{O}_{3}\right)$ після підвищення температури понад $1500-1550^{\circ} \mathrm{C}$. Найбільш раціональним та доцільним, враховуючи час рафінування супутнього металу, є алгоритм процесу з присадкою вказаних матеріалів 2- 3 порціями.

Таким чином, найбільш раціональним інтервалом витрати загального кисню $€ 11-15 \mathrm{~m}^{3} / 100 к г$ супутнього металу, що забезпечить максимально високий перехід марганцю з металевої у шлакову фазу з достатньо низьким вмістом в ній фоосфору та оксидів заліза при максимальному використанні окислювального потенціалу кисню повітря, що витрачається для продувки металевої ванни, та кисню окалини.

Теплота від окислювання марганцю супутнього металу становить основну частину приходу теплової енергії, за рахунок якої значно підвищується температура металу та шлаку.

При продувці металевого та шлакового розплавів повітрям без їх примусового охолоджування температура може підвищитися до $2000^{\circ} \mathrm{C}$ і вище за рахунок приходу теплоти від реакцій окислювання марганцю, кремнію, вуглецю та частки заліза киснем, що містять повітря та окалина. Кінцева температура марганцевого шлаку з прогнозуємо високим вмістом $\mathrm{MnO}$ та залишків металевої фази на основі заліза, марганцю та фосфору при низькому вмісті в ній вуглецю та кремнію визначається температурою плавлення металевої фази і повинна становити приблизно $1500^{\circ} \mathrm{C}$.

Враховуючи значення ефектів охолодження, що досягаються при використанні ряду досліджених матеріалів, обґрунтовано, що для зниження температури металу та шлаку з отриманням шлакової фрази з необхідними фізичними характеристиками найбільш раціонально використовувати кварцит, магнезит та прокатну окалину. Вибір вказаних матеріалів в якості компонентів флюсу також ґрунтується на їх нейтральності по відношенню до $\mathrm{P}_{2} \mathrm{O}_{5}$, утворення якого не заперечується термодинамікою, особливо, при суттєвому зниженні в рідкому металі, що продувається повітрям, марганцю, кремнію та вуглецю. 3 метою суттєвого обмеження або повного виключення переходу фосфору з металу в шлак з компонентів, що формують фрлюс, необхідно виключати вапно.

Термодинамічними розрахунками встановлено, що при загальній витраті кисню $13 \mathrm{~m}^{3}$ зниження температури металу і шлаку до температури їх випуску $\left(\sim 1600^{\circ} \mathrm{C}\right)$ досягається за рахунок присадки 
17кг окалини, 4 кг $\mathrm{MgO}$, та $30 к г \mathrm{SiO}_{2}$ з урахуванням охолоджувального ефекту $37,77 \mathrm{~m}^{3}$ азоту при відповідній витраті повітря 47,6м ${ }^{3}$. Доцільно використовувати як верхню та і інші способи продувки (донну та комбіновану).

Таким чином при реалізації приведеного вище алгоритму режимів дуття та шлакоутворення можна забезпечити отримання мало фосфористого шлаку та залишків металу, близького за вмістом до ферофросфору. В подальшому одержаний мало фосфористий марганцевий шлак може бути використано для виробництва металевого марганцю, переробного силікомарганцю або низьковуглецевого феромарганцю, а ферофросфор - для легування автоматних сталей, для виробництва антифрикційних чавунів, для підвищення рідко плинності чавунів.

Аналіз результатів розрахунку теплового балансу продувки супутнього металу повітрям з урахуванням раціонального обґрунтованої витрати окислювача (кисню повітря та прокатної окалини), приросту теплової енергії від окислення домішок (Mn, C, Si, Fe) та її втрат с азотом і охолоджувачами, дозволив розробити раціональний алгоритм ведення процесу, який полягає у наступному.

При підвищенні температури металу та шлаку з $1300^{\circ} \mathrm{C}$ до $\sim 1500^{\circ} \mathrm{C}$, що відповідає витраті кисню (який входить до складу повітря), біля $5 \mathrm{~m}^{3}$, додається перша частка прокатної окалини (половина від її загальної кількості, що містить 1,5м ${ }^{3}$ кисню) та перша частка фрюсів (кремнезему та магнезиту), яка також становить половину від їх загальної кількості. Це призводить до зниження температури в системі метал - шлак та темпу її зростання за рахунок використання частки теплової енергії (від окислення домішок супутнього металу) на нагрів і плавлення флюсів. Також можливе використання залізної руди або її концентрату замість окалини. В подальшому при витраті кисню повітря $5 \mathrm{~m}^{3}$ (загальному 10 м3) і досягненні температури металу та шлаку $1500-1550^{\circ} \mathrm{C}$, додається друга частка прокатної окалини, що становить половину від загальної (8,5 кг), що містить $\sim 1,5 \mathrm{~m}^{3}$ кисню, а для охолодження металевого та шлакового розплавів присаджується розрахункова залишкова частка флюсу-охолоджувача, яка становить при дворазовому його присаджуванні на поверхню ванни половину від загальної кількості. При проведенні високотемпературного моделювання рафінування сплаву в лабораторних умовах із-за значно більших втрат теплоти з агрегатом садкою 30кг процес було здійснено з триразовою присадкою окалини та флюсів.

При загальній витраті кисню, що становить біля $13 \mathrm{~m}^{3}$, отримання заданої температури випуску марганцевого шлаку та залишків металевої фрази $\left(\sim 1600^{\circ} \mathrm{C}\right)$ досягається шляхом реалізації запропонованої схеми присадки вказаних вище компонентів (окислювачів та флюсів). Доцільно після закінчення продувки повітрям проводити короткочасну продувку металевої ванни нейтральним газом (ар- гоном або азотом) впродовж 1 хв. для доведення реакцій окислювання марганцю оксидами заліза, що мають місце на межі шлак - метал до більш повного їх завершення.

Вибір найбільш раціонального алгоритму режиму дуття і шлакооутворення визначається особливостями реальної кінетики окислювальних реакцій в, основному, зміною інтенсивності реакції окислювання вуглецю металевого розплаву. При суттєвому збільшенні інтенсивності окислювання вуглецю, що відповідає підвищенню температури до $\sim 1450^{\circ} \mathrm{C}$ і приводить до значного підвищення газоподібних продуктів, що утворюються в об'ємі металевого розплаву, доцільно знизити в цей період питому витрату повітря. Після введення присадок флюсів та окалини для охолодження металевої ванни при суттєвому зниженні вмісту в металі вуглецю ( до 0,2 $\div 0.3 \%$ ), питома витрата повітря може бути підвищена до оптимальної.

Таким чином, позитивні ефекти за рахунок реалізації способу отримання мало фосфористого марганцевого шлаку, ґрунтуються на заміні газу для продування (кисню на повітря), зниженні кількості компонентів флюсу та окалини, вилучення зі складу флюсу оксидів лужних елементів і проявляються в збільшенні продуктивності процесу, заснованого на використанні високо фосфористого сплаву, підвищення ступеню наскрізного вилучення марганцю з вихідної сировини, зниженні собівартості отриманого з відходу продукту при його достатньо високій якості та отриманні додаткового побічного продукту, за складом близьким до ферофосфорору.

\section{ВИСНОВКИ}

Фізико-хімічна сутність пропонованої схеми рафінування високо фосфористого марганцевого сплаву полягає в створенні умов для окислення здебільшого марганцю, вуглецю і кремнію сплаву.

Термодинамічний прогноз перебігу реакцій в заданих умовах окислювального рафінування супутнього металу підтверджує можливість отримання двох продуктів: мало фосфрористого марганцевого шлаку і розплаву на основі заліза і фосфору. Рафінування сплаву при температурі $1500^{\circ} \mathrm{C}$ може забезпечити отримання мало фосфористого шлаку наступного складу\% мас.: $\mathrm{MnO}$ - 61,8; $\mathrm{FeO}$ 0,95; $\mathrm{SiO}_{2}$ - 31,79 і (P) - 0,033, а також металу: C 0,27; Si - 3,08-10 ${ }^{-5}$; P - 7,49; Mn - 6,84 i Fe - 84,19.

На підставі вивчення термодинамічних залежностей результатів високотемпературних експериментів встановлено, що найбільш раціональною витратою кисню, що забезпечує досягнення поставлених завдань $€ \sim 13 \mathrm{~m}^{3}$. Доцільно в якості окиснювачів використовувати кисень повітряного дуття, який вводиться в ванну за допомогою продувної фурми зверху і прокатної окалини. При цьому загальна витрата повітря на 100кг сплаву повинен становити близько $50 \mathrm{~m}^{3}$ і окалини близько 17 кг.

У роботі на основі термодинамічної прогнозу поведінки елементів супутнього сплаву в окислювальних умовах, оцінки теплової сторони процесу і 
подальшої експериментальної перевірки, отримані результати, що підтверджують можливість ство- рення безвідходної технологічної схеми проведення рафрінування високо фросфористого сплаву.

\section{ЛИТЕРАТУРА}

1. Спосіб дефосфорації рідкого вуглецевого феромарганцю з підвищеним вмістом кремнію. № 114147. Мяновська Я.В., Пройдак Ю.С.,Камкіна Л.В., Мішалкін А.П.,Грищенко Ю.Н. Публікація відомостей 25.04.2017, Бюл. №8.

2. Исследование восстановительной дефоссоорации расплавов марганца/ В.Я. Дашевский, АМ. Кацнельсон, Д.Л. Маслов и др.// Изв. АН СССР. Металлы. - 1994. -№5.- С. 22-26.

3. Гасик М.И. Теория и технология производства ферросплавов / М.И. Гасик, Н.П. Лякишев, Б.И. Емлин. - М.: Металургия, 1988. $783 \mathrm{c}$.

4. Толочко М. В., Кондаков Э. В. Теоретический анализ возможности дефоссрорации попутного ферромарганца и получения на его основе высокомарганцовистого чугуна //Теория и практика металлургии. - 2005. - №. 4/5. - С. 26-27. и др.

5. Fraser A Armstrong. Why did Nature choose manganese to make oxygen? Philos Trans R Soc Lond B Biol Sci. 2008; 363(1494): 1263-1270. doi: 10.1098/rstb.2007.2223

6. Vincent L. Pecoraro, Michael J. Baldwin, Andrew Gelasco. Interaction of Manganese with Dioxygen and Its Reduced Derivatives. Chem. Rev. 1994, 94, 3, 807-826. 1994. https://doi.org/10.1021/cr00027a012

7. Post JE. Manganese oxide minerals: Crystal structures and economic and environmental significance. Proc. Natl. Acad. Sci. USA. 1999;96:3447-3454. doi: 10.1073/pnas.96.7.3447

8. Matthias Augustin, Daniela Fenske, Ingo Bardenhagen, Anne Westphal, Martin Knipper, Thorsten Plaggenborg, Joanna KolnyOlesiak, Jürgen Parisi. Manganese oxide phases and morphologies: A study on calcination temperature and atmospheric dependence. Beilstein J Nanotechnol. 2015; 6: 47-59. doi: 10.3762/bjnano.6.6

9. Mn oxide formation by phototrophs: Spatial and temporal patterns, with evidence of an enzymatic superoxide-mediated pathway. Dominique L. Chaput, Alexandré J. Fowler, Onyou Seo, Kelly Duhn, Colleen M. Hansel, Cara M. Santelli. Sci Rep. 2019; 9: 18244. doi: 10.1038/s41598-019-54403-8

10. Гасик М.И. Марганец / М.И. Гасик. - М.: Металлургия, 1992. - 608 с.

11. Гасик М.И. Фосфор в никопольских марганцевых рудах и его поведение при выплавке марганцевых ферросплавов / М.И. Гасик, В.Ф. Горбачев, С.И. Хитрик // Изв. вузов. Черная металлургия. - 1972. - №8. - С. 69-75.

12. Shin D.J., Gao X., Ueda S., Kitamura S.-Y. Selective Reduction of Phosphorus from Manganese Ore to Produce Ferromanganese Alloy with Low Phosphorus Content. Journal of Sustainable Metallurgy. Volume 5, Issue 3, 15 September 2019, Pages 362-377. DOI: 10.1007/s40831-019-00227-9.

13. Xi X., Yang S., Li J., Luo D., Cai X., Lai C. Phosphorus distribution between rare earth oxides containing slags and ferromanganese alloy. Ironmaking and Steelmaking. Volume 46, Issue 5, 28 May 2019, Pages 485-490. DOI: 10.1080/03019233.2017.1405151.

14. Kim D.-Y., Kim H.-S., Jung S.-M. PRoduction of (Mn,Fe)-carbide containing low phosphorus by carbothermic reduction of Mn oxide and Fe oxide. Engineering Solutions for Sustainability: Materials and Resources II. 2016, Pages 73-83. DOI: 10.1007/978-3-319-48138-8_6

15. Диаграммы состояния двойных металлических систем: Справочник в 4-х т. / Под. ред. академика Н.П. Лякишева. Т.2. - М.: Машиностроение. -1997. - С. 509-510.

16. Lee, Y.E. Thermodynamics of the Mn-P system. Metallurgical Transactions B. Volume 17, Issue 4, December 1986, Pages 777783. DOI: $10.1007 / \mathrm{BF} 02657140$

17. FactSage thermochemical software and databases - recent developments. Bale C.W., Bélisle E., Chartrand P., Decterov S.A., Eriksson G., Hack K., Jung I.-H., Kang Y.-B., Melançon J., Pelton A.D., Robelin C., Petersen S. Calphad: Computer Coupling of Phase Diagrams and Thermochemistry. Volume 33, Issue 2, June 2009, Pages 295-311. DOI: 10.1016/j.calphad.2008.09.009.

18. Xi X., Yang S., Li J., Luo D., Cai X., Lai C. Phosphorus distribution between rare earth oxides containing slags and ferromanganese alloy. Ironmaking and Steelmaking. Volume 46, Issue 5, 28 May 2019, Pages 485-490. DOI: 10.1080/03019233.2017.1405151

19. Fujita Masaki, Katayama Hiroyuki, Yamamoto Akira, Matsuo Michitaka. DEPHOSPHORIZATION OF Fe-Mn-C ALLOY WITH BaCO3. Tetsu-To-Hagane/Journal of the Iron and Steel Institute of Japan. Volume 74, Issue 5, May, Pages 816-822. DOI: 10.2355/tetsutohagane1955.74.5_816

20. Joo, S.-W., Hong, S.-H., Lee, G.-H., You, B.-D. Evaporation behavior of low carbon ferromanganese alloy melt at reduced pressure. Metals and Materials International. Volume 19, Issue 3, May 2013, Pages 585-590. DOI: 10.1007/s12540-013-3030-x

21. Гасик, М. И. Теория и технология электрометаллургии ферросплавов: Учебник для вузов / М. И. Гасик, Н. П. Лякишев. - М.: СП Интермет Инжиниринг, 1999. -764 с.

22. Kim D.-Y., Kim H.-S., Jung S.-M. PRoduction of (Mn,Fe)-carbide containing low phosphorus by carbothermic reduction of Mn oxide and Fe oxide. Engineering Solutions for Sustainability: Materials and Resources II. 2016, Pages 73-83. DOI: 10.1007/978-3-319-48138-8 6

23. Эллиот Д.Ф., Глейзер М., Рамакришна В. Термохимия сталеплавильных процессов. Справочник. - М.: Металлургия, 1969. $-252 \mathrm{c}$.

24. Розенгарт Ю. И. Вторичные энергетические ресурсы черной металлургии и их использование / Ю. И. Розенгарт, Б.И. Якобсон, 3. А. Мурадова // К.: Вища школа. Головное изд-во, 1988. - 328 с.

25. Smirnov L.A., Rovnushkin V.A., Smirnov A.L., Shul'min D.S. Conversion of vanadium hot metal in a flux-free converter process. Steel in Translation. 2015. T. 45. № 5. C. 356-360.

26. R.R Moskalyk, Akram Alfantazi. Processing of Vanadium: A Review. 2003. Minerals Engineering 16(9):793-805. DOI: 10.1016/S0892-6875(03)00213-9.

27. Mineral Processing and Metallurgical Treatment of Lead Vanadate Ores. Ivan Silin, Klaus M. Hahn, Devrim Gürsel, Dario Kremer, Lars Gronen, Srećko Stopić, Bernd Friedrich, Hermann Wotruba. Review. Minerals 2020, 10, 197; doi:10.3390/min10020197

28. Wang, M.; Huang, S.; Chen, B.; Wang, X. A review of processing technologies for vanadium extraction from stone coal. Miner. Process. Extr. Metall. 2018, 1-9, doi:10.1080/25726641.2018.1505207

29. Hai-Xing FANG, Hong-Yi LI, Tao ZHANG, Bao-Si LIU, Bing XIE. Influence of $\mathrm{CaO}$ on Existence form of Vanadium-containing Phase in Vanadium Slag. ISIJ International, Vol. 55 (2015), No. 1, pp. 200-206. 